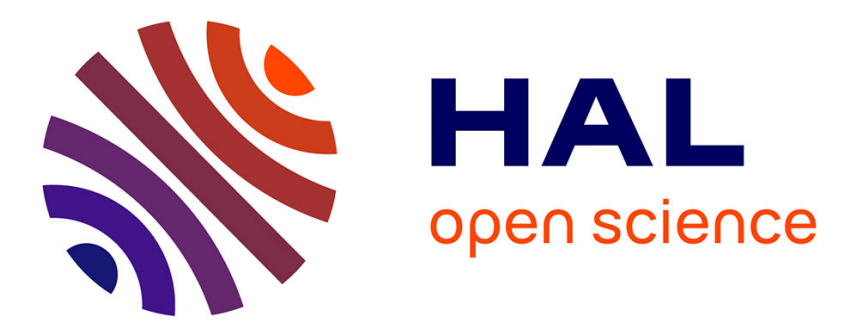

\title{
Biomarkers for immune intervention trials in type 1 diabetes.
}

\author{
Roberto Mallone, Bart O. Roep
}

\section{To cite this version:}

Roberto Mallone, Bart O. Roep. Biomarkers for immune intervention trials in type 1 diabetes.. Clinical Immunology, 2013, epub ahead of print. 10.1016/j.clim.2013.02.009 . inserm-00806093

\section{HAL Id: inserm-00806093 https://www.hal.inserm.fr/inserm-00806093}

Submitted on 29 Mar 2013

HAL is a multi-disciplinary open access archive for the deposit and dissemination of scientific research documents, whether they are published or not. The documents may come from teaching and research institutions in France or abroad, or from public or private research centers.
L'archive ouverte pluridisciplinaire HAL, est destinée au dépôt et à la diffusion de documents scientifiques de niveau recherche, publiés ou non, émanant des établissements d'enseignement et de recherche français ou étrangers, des laboratoires publics ou privés. 
Biomarkers for immune intervention trials in type 1 diabetes

Roberto Mallone $e^{a, b, c}$ and Bart O. Roep ${ }^{d, e}$

${ }^{a}$ Cochin Institute, INSERM U1016, DeAR Lab Avenir, Paris, France ;

${ }^{\mathrm{b}}$ Paris Descartes University, Sorbonne Paris Cité, Faculté de Médecine, Paris, France ;

${ }^{c}$ Assistance Publique Hôpitaux de Paris, Hôtel Dieu, Service de Diabétologie, Paris, France ;

${ }^{\mathrm{d} D e p a r t m e n t}$ of Immunohaematology \& Blood Transfusion, Leiden University Medical Center, Leiden, The Netherlands;

${ }^{\mathrm{e} N a t i o n a l ~ D i a b e t e s ~ E x p e r t ~ C e n t e r . ~}$

\section{Corresponding Authors:}

Roberto Mallone, DeAR Lab Avenir, INSERM U1016, Hôpital Saint Vincent de Paul -

82 avenue Denfert Rochereau - 75674 Paris Cedex 14 - France. Phone : +33-158.41.48.15. E-mail: roberto.mallone@inserm.fr

Bart Roep, Department of Immunohaematology \& Blood Transfusion E3Q, P.O. Box 9600, NL2300RC Leiden University Medical Center, Leiden, The Netherlands. Phone: +31-71-526.3800. E-mail: B.O.Roep@lumc.nl 


\begin{abstract}
After many efforts to improve and standardize assays for detecting immune biomarkers in type 1 diabetes (T1D), methods to identify and monitor such correlates of insulitis are coming of age. The ultimate goal is to use these correlates to predict disease progression before onset and regression following therapeutic intervention, which would allow performing smaller and shorter pilot clinical trials with earlier endpoints than those offered by preserved $\beta$-cell function or improved glycemic control. Here, too, progress has been made. With the emerging insight that T1D represents a heterogeneous disease, the next challenge is to define patient subpopulations that qualify for personalized medicine or that should be enrolled for immune intervention, to maximize clinical benefit and decrease collateral damage by ineffective or even adverse immune therapeutics. This review discusses the current state of the art, setting the stage for future efforts to monitor disease heterogeneity, progression and therapeutic intervention in T1D.
\end{abstract}

Keywords: autoantibodies; C-peptide; endpoint; T cells. 


\section{Introduction}

Type 1 diabetes (T1D) represents a prototypic tissue-specific autoimmune disease [1]. Indeed, progress in unraveling the immune components involved in the pathogenesis of T1D has been spectacular and often more rewarding than for other autoimmune diseases. Several islet antigens (Ags) have been identified with compelling associations with the $\beta$-cell destruction process, including (pre)proinsulin [(pre)PI], glutamic acid decarboxylase (GAD)65, insulinoma-associated protein 2 (IA2), islet-specific glucose-6-phosphatase catalytic subunit-related protein (IGRP) and zinc transporter $(\mathrm{ZnT}) 8$ [2-4]. Additional candidate target molecules expressed by $\beta$ cells have been revealed and studied, such as chromogranin A, (prepro) islet amyloid polypeptide (pplAPP), peripherin and an ill-defined $38 \mathrm{kDa}$ protein in insulin secretory granules, but their role in and association with clinical T1D remains unclear or controversial [5]. The immunology of diabetes community has been blessed with this large series of T-cell and/or autoantibody (autoAb) targets that can be employed in monitoring the islet autoreactivity of T1D [6]. Islet autoAbs against many of these Ags have proven particularly useful for T1D prediction, but less so for following disease activity and progression after T1D onset or during therapeutic intervention (so called "immune staging") [7]. This notion is putting a substantial burden on the options to monitor changes in disease activity. It implies that we may have to resort to using cellular autoimmunity to this end, with all the challenges involved in terms of technologies and targets.

New access to the pancreatic lesions of T1D patients through the establishment of an international consortium collecting, distributing and characterizing tissues of diabetic donors (www.jdrfnpod.org) has led spectacular new insights into the immune processes involved in the selective destruction of insulin-producing $\beta$ cells in 
pancreatic islets [8]. Seminal recent lessons learned through these studies include additional proofs of the autoimmune nature of T1D, the demonstration of islet-specific $\mathrm{CD}^{+} \mathrm{T}$ cells in destructive insulitic lesions, the unexpectedly low frequencies of isletinfiltrating $\mathrm{CD}^{+} \mathrm{T}$ cells, the apparent lack of $\mathrm{CD} 4^{+} \mathrm{CD} 25^{+} \mathrm{FoxP} 3^{+} \mathrm{T}$ regulatory cells (Tregs) in insulitis, the profound difference in immunopathology between men and mice, an overwhelming heterogeneity in the pathologic lesions and patient population, and the demonstration of focal disease activity much akin to what observed in other tissue-specific autoimmune diseases such as vitiligo [9]. Collectively, these insights have set the stage for new therapeutic strategies that may also prove effective in protecting $\beta$ cells long after T1D clinical onset. Many of these strategies are currently assessed for clinical efficacy to prevent, stop of reverse disease. Some recent-onset T1D patients have already achieved a lasting remission from insulin dependency for up to seven years, showing proof of principle that T1D may be cured, at least in some patients and at least for a number of years [10]. Yet, there is an urgent need for definition of endpoints and biomarkers of immunological and clinical efficacy to guide therapeutic interventions in T1D. The immune system holds important clues to provide immune correlates of safety and clinical efficacy, both for selecting the appropriate patients for a given therapy and to monitor whether the intervention can preserve $\beta$-cell function.

\section{T1D: a T-cell-mediated autoimmune disease}

T1D is an autoimmune disease in which $C D 4^{+}$and $C D 8^{+} \mathrm{T}$ cells infiltrate the islets of Langerhans, resulting in $\beta$-cell destruction. Although the precise etiologic factors remain barely elusive, an extensive body of data in animal models and more limited studies in man indicate that, contrary to autoAbs [11], $C D 4^{+}$and $C D 8^{+} \mathrm{T}$ cells reactive 
with islet Ags have a key role in the process of $\beta$-cell destruction. The lines of evidence gathered in mouse models have been extensively reviewed, and the notion of a central pathogenic role for $\mathrm{T}$ cells in the diabetes of non-obese diabetic (NOD) mouse models is widely accepted. Focusing on data from human studies, one first line of evidence comes from histological analyses of pancreata from newly diagnosed T1D patients, showing abundant $\mathrm{T}$ cells, mostly $\mathrm{CD}^{+}$, present in the islet inflammatory infiltrates ("insulitis"). In situ HLA Class I tetramer staining analyses have pinpointed the specificity of these infiltrating $\mathrm{CD}^{+} \mathrm{T}$ cells, proving that they are indeed islet-reactive [8].

Second, some immunosuppressive drugs, including those specifically directed against T cells, confer some delay in T1D progression. For example, therapy with non-activating humanized monoclonal antibodies against the T-cell surface molecule CD3 at T1D onset suggests some $\beta$-cell preservation, although the doses needed to achieve such effect raised safety concerns $[12,13]$.

Third, CD8 ${ }^{+}$T-cell-mediated islet autoimmunity in association with T1D onset [14-17] and loss of islet-graft function [18] provides evidence that the peripheral blood represents a "window" through which anti-islet T-cell reactivity can be followed, reflecting the autoimmune activity present locally in the islet infiltrates [19]. CD4 ${ }^{+} \mathrm{T}$ cells specific for islet Ags are also circulating in T1D patients and display a proinflammatory memory phenotype $[20,21]$. This is at variance with what observed in non-diabetic control subjects, which sometimes harbour islet-reactive $\mathrm{T}$ cells displaying a putative regulatory phenotype characterized by IL-10 production. Indeed, T1D patients harbouring CD4+ $T$ cells that produce $\mathrm{IL}-10$ in response to islet epitopes developed clinical T1D on average 7 years later than those not producing IL-10 [20]. Similar observations have been reported for islet-reactive $\mathrm{CD}^{+} \mathrm{T}$ cells 
[22]. These seminal reports invite the hypothesis that IL-10 induction by islet Agspecific tolerogenic vaccination may halt disease progression and preserve $\beta$-cell function.

Apart from these examples of studies documenting an association between T-cell activity and $\beta$-cell destruction, gathering direct evidence for a cause-effect relationship has been more daunting. Such evidence has been provided in vitro, documenting that prePI-reactive CD8+ T-cell clones are capable of destroying human islets $[23,24]$. Expanding these observations, T1D patient derived autoreactive CD4 ${ }^{+}$ T-cell clones injected into NOD.scid mice along with HLA-matched human Agpresenting cells migrated to the islets, resembling early peri-islet insulitis [25]. Similarly, NOD. $\beta 2 m^{\text {null }} . H H D$ transgenic mice carrying a human HLA-A2 transgene and thus HLA-A2-restricted CD8+ $T$ cells documented that CD8+ $T$ cells isolated from their islets are able to lyse human HLA-A2 ${ }^{+}$islets [26]. Patient-derived CD8+ $\mathrm{T}$ cell clones with this same islet specificity and injected into NOD. $\beta 2 m^{\text {null }} . H H D$ mice lyse human transplanted target cells and home to the endogenous islets [27], causing insulitic lesions resembling those in new onset T1D patients [8]. Some of the epitopes targeted by these murine diabetogenic T-cell clones are identical to that of human $\mathrm{CD}^{+} \mathrm{T}$-cell clones $[15,28]$. Similar observations have been reported for GAD-reactive $\mathrm{CD}^{+} \mathrm{T}$ cells, which were able to destroy $\beta$ cells when co-transplanted with human islets into immunodeficient mice [29]. Although this was not the case for control-reactive $\mathrm{CD}^{+} \mathrm{T}$ cells, the use of HLA-mismatched human islets complicates interpretation.

Taken together, these data lend support for a central pathogenic role of islet-reactive T cells in T1D autoimmunity. 


\section{Endpoints in immune intervention trials: metabolic and immune biomarkers}

To put into context the endpoints analyzed in T1D intervention trials, the clinical stage at which most of these trials are performed should be kept in mind. While in the NOD mouse models, which is commonly used to preclinically evaluate the efficacy of immune therapeutics, treatment is usually started as early as possible, at a time when the autoimmune progression is still lagging behind, this is not feasible in patients. Indeed, autoAbs are the earlier available biomarkers of T1D risk. While extremely useful, they also provide proof that the autoimmune process is already floridly active. Moreover, the earliest detection of one single autoAb (typically targeting insulin in children) does not mark a risk considered high enough to justify immune intervention. Indeed, only $\sim 10 \%$ of those individuals who are single autoAb+ progress to T1D during the following 5 years [30]. Individuals who develop additional autoAb reactivities during follow up significantly increase their risk of developing T1D ( $80 \%$ at 5 years) [30], reflecting their more advanced stage of autoimmune progression and Ag spreading. However, also in this case the risk-benefit balance poses delicate ethical issues in T1D. This is because, contrary to more deadly diseases, the prognosis of T1D once disease is diagnosed is relatively benign for several decades and life expectancy approaches that of healthy subjects when glycemic control is satisfactory. If we add that most at-risk individuals have high yet not ineluctable odds of progressing to T1D, it is clear that the "treat/not treat" equation is difficult to solve, especially when using immune therapeutics with unknown long-term benefits and harms. It is for all these reasons that most intervention trials are performed soon after and not before T1D onset. At this time, not only $\beta$-cell autoimmunity is far advanced, but also a consistent fraction of the $\beta$ cell mass has already been destroyed. 
The exact fraction of remaining $\beta$ cells is a matter of debate and is highly variable, ranging from as low as $15 \%$ in children to as high as $60 \%$ in adults [31]. Moreover, although it is increasingly suggested that this $\beta$-cell mass may regenerate to some extent, definite evidence is lacking. It appears that even the most effective immune therapy capable of completely halting autoimmunity may only rescue a limited $\beta$-cell function. The challenge embraced by immune intervention trials performed at T1D onset is therefore a daunting one.

While clinical endpoints such as HbA1c values and insulin needs are part of trial follow-ups, they are exposed to a number of confounding variables such as lifestyle, insulin sensitivity and practices of different diabetologists which make them of limited reliability. Hence, the most widely used endpoints are metabolic biomarkers which should more reliably reflect the degree of $\beta$-cell preservation. This is assessed by measuring C-peptide secretion (which is equimolar to insulin secretion) following $\beta$ cell stimulation with a standardized meal (so called "mixed meal tolerance test") [32]. While these endpoints provide the most accurate estimation of clinical efficacy to date, they have important limitations. First, given the advanced stage of islet damage, the modifications to be expected in these parameters are limited. Said otherwise, we may conclude that an intervention is ineffective while it could have been beneficial if administered at an earlier time point, i.e. before T1D onset. Second, limited metabolic changes also mean higher patient numbers that need to be enrolled to provide sufficient statistical power to conclude for a clinical benefit. Third, metabolic parameters can only be assessed at the end of the trial, thus taking several months or years. Fourth, recent awareness has risen suggesting that $\beta$-cell function need not equal $\beta$-cell mass. Indeed, the persistence of $\beta$ cells and insulin production as well as inflammatory insulitic lesions many years after clinical T1D onset have been reported 
[8]. Moreover, there is an apparent discordance between $\beta$-cell mass and function, which may reflect some degree of $\beta$-cell quiescence reminiscent of "stunned" myocardiocytes in ischemic heart disease. These elements make it more challenging to sensitively measure residual $\beta$-cell capacity late after T1D onset. This further invites the use of other endpoints such as immune correlates of disease progression and therapeutic intervention [33]. Such new endpoints may decrease time required to assess therapeutic efficacy and allow for smaller numbers of patients per treatment arm.

There are therefore several good reasons to include immune biomarkers in the follow-up of immune intervention trials [7]. First, these biomarkers can change quite rapidly, already some weeks or months after treatment, thus providing earlier endpoints than those delivered by metabolic measures. Second, immune biomarkers provide key information about immunological efficacy, i.e. to assess whether the type of immune deviation that was aimed has been achieved. This information is even more critical when the clinical outcome is not improved, as it allows to sort out between two explanations: is this due to lack of immune efficacy? Or rather, is immune efficacy obtained yet insufficient to provide significant clinical benefit? Third, immune biomarkers may provide indications on how to perform better in subsequent trials, by identifying immune signatures associated with clinical benefits. Such immune signatures may be present before treatment, allowing to enroll only those patients with the best chances to respond; or during intervention, informing decisions on whether to continue treating or not.

\section{Why using $T$ cells rather than autoAbs as immune biomarkers for trial monitoring?}


AutoAbs remain the mainstay for classifying diabetes cases as autoimmunemediated (type 1) and for stratifying risk in first-degree relatives. Can their modifications also be used as immune biomarkers in trial follow-ups? This was performed for instance in an anti-CD3 phase II trial in new-onset T1D patients [34]. Despite evidence for a better preservation of residual insulin secretion in anti-CD3vs. placebo-treated patients, there was no significant change in autoAb titers. Lack of modifications in autoAb titers could simply reflect the fact that $T$ cells but not $B$ cells are targeted by anti-CD3 treatment. Indeed, the recent T1D TrialNet trial employing the anti-CD20 Ab rituximab [35], which instead targets Ag-presenting B cells, documented disappearance of anti-insulin autoAbs (IAAs) in $40 \%$ of rituximab-treated patients vs. $0 \%$ of placebo-treated ones, both IAA+ before treatment [36].

Ag vaccination trials have also invited to analyze changes in humoral immunity not in terms of preexisting autoAb responses, but rather of $A b$ developing against the exogenous vaccinal $\mathrm{Ag}$. This has been documented in the GAD-alum vaccination trials, where subcutaneous administration was followed by a steep rise in anti-GAD Abs peaking at 3 months [37], which subsequently persisted at lower titers up to the latest available 4-year follow-up [38]. Nonetheless, whether this rise should be regarded as a biomarker suggestive of a favorable immune outcome is unclear. On one side, Ab responses are frequently associated with a T helper 2 (Th2) deviation of T-cell responses, which represent a potentially desirable effect shifting away from more pathogenic Th1 responses. On the other hand, Ag-specific Abs can also favor activation of cognate $\mathrm{T}$ cells, at least in vitro [39]. Thus, also in the case of $\mathrm{Ag}$ vaccination trials, it seems important to interpret these changes in $A b$ titers to exogenously administered Ags in light of the associated changes in the corresponding T-cell responses. This was performed in the intranasal insulin 
prevention trial, where at-risk individuals treated with the active compound displayed a rise in Abs against exogenous insulin along with a concomitant decline in insulinstimulated proliferative T-cell responses [40].

These results argue against the (exclusive) use of autoAbs as immune biomarkers for trial monitoring. First, T1D is a T-cell-mediated autoimmune disease and most therapeutic strategies target this lymphocyte population. Second, autoAb secretion is provided by long-lived plasma cells, while memory B cells can further differentiate into plasma cells in the case of persistent or recurrent Ag stimulation. Such dynamics are largely T-cell-independent once the primary immune response has subsided, making changes in autoAb titers slow in kinetics and poorly influenced by concomitant changes in the corresponding Ag-specific T-cell compartments. A third reason is offered by the more rapid modifications of T-cell responses compared to (auto)Ab-producing B cells. Evidence for such different kinetics was gathered in newonset T1D patients followed for both autoAb and T-cell responses at diagnosis and after a median follow-up of 11 months. While GAD and IA-2 autoAb titers were unchanged in $75 \%$ of cases, the fraction of patients displaying IFN- $\mathrm{Y}$-secreting T-cell responses specific for prePI and/or GAD epitopes decreased from $\sim 65 \%$ to $20 \%$ [28]. In this "spontaneous" setting, i.e. in the absence of immune intervention, this modification in T-cell responses may be due either to decreased Ag stimulation owing to a decline in the $\beta$-cell mass; or to a tolerogenic effect of insulin therapy $[41,42]$.

\section{Measuring T-cell responses in T1D}

In front of the advantages of monitoring T-cell rather than autoAb responses, there are also some drawbacks, namely that T-cell assays are technically more demanding [43-46]. These assays employ live peripheral blood mononuclear cells (PBMCs), 
which should be prepared and stored following procedures not routinely implemented in clinical laboratories. Following the successful efforts of the Diabetes Antibody Standardization Program (DASP) over the last two decades, the T-Cell Workshop initiative of the Immunology of Diabetes Society is providing guidelines on how to handle these biological samples [44]. The other key mission of the T-Cell Workshop is to launch multicentre initiatives to independently validate and standardize T-cell assays which have performed well in single-center studies [47].

Another obvious challenge is that T-cell assays are better poised to detect relevant biomarkers when used to analyze responses against $\beta$-cell Ags rather than polyclonal T-cell responses as a whole. Arguably, analyzing T-cell responses independently of their Ag specificity is like analyzing titers of the whole Ab repertoire of a given individual. It is conceivable that treatments that are deemed to be nonimmunosuppressive or even Ag-specific will induce changes that remain undetectable at a polyclonal level. If polyclonal changes are detectable, they may even suggest that the tolerogenic effect is not selective enough and that a generalized immunosuppression is instead achieved. There is therefore a pressing need for robust assays capable of measuring the physical disappearance or functional silencing of islet-reactive $\mathrm{T}$ cells, or the appearance/activation of Treg populations. This need is most compelling in the setting of immune intervention trials, to provide readouts for the $\mathrm{T}$ cells that are targeted by most therapies. To perform Tcell assays of this kind, it is therefore essential to continue mapping the molecular targets (Ags and epitopes thereof) recognized by such T cells.

\section{Applications of immune biomarkers for trial monitoring}


Monitoring of clinical trials by means of immune biomarkers can address a number of questions posed by immune interventions (Figure 1). Such questions fall into three main categories: therapeutic safety, i.e. are we causing unwanted immune activation or, conversely, are we inducing generalized immune suppression?; immunological efficacy, i.e. did we achieve the immune deviation that we set out for?; and, ultimately, therapeutic efficacy, i.e. is the immunological change achieved associated with clinical efficacy?

\subsection{Immune biomarkers of therapeutic safety}

Negative clinical outcomes of an immune therapeutic intervention can sometimes be revealed by accelerated disease progression, as defined by worsening glycemic control, increased insulin needs or decreased $\beta$-cell function. While disease acceleration has been observed in immunotherapy trials performed in other autoimmune diseases such as multiple sclerosis [48], this has fortunately not been the case for T1D. The same is true for acute development of clinical complications, with the only partial exception of EBV reactivation during the European "high-dose" anti-CD3 phase II trial [34]. Several mainstream immune and viral biomarkers are routinely used to monitor and pre-empt such adverse events. Unwanted type I immune activation can also be promptly revealed by allergic or skin reactions, anaphylaxis or eosinophilia.

One more difficult question to address is whether the immune intervention is truly inducing a state of (islet-specific) immune tolerance or rather one of generalized immune suppression, be it in the absence of or despite obvious laboratory abnormalities such as lymphopenia. Given the lack of suitable parameters to gauge the in vivo responsiveness of the immune system [49], one way to address this is to 
vaccinate patients with an irrelevant neo-Ag during treatment follow-up and to subsequently assess the efficacy of such vaccination in terms of immune responses. Although only naïve responses are evaluated, such approach provides a useful proxy of suitable immune competence to minimize the risk of viral infections/reactivations and secondary tumor growth. This strategy has been applied in the TrialNet antiCD20 trial, where treated patients were immunized with the phiX174 neo-Ag following B-cell recovery and developed normal IgM titers [35]. Wider evaluation of these safety parameters would be desirable for T1D trials, and active research is ongoing to define simplified in vitro measures predictive of subsequent in vivo response to $\mathrm{Ag}$ challenges. On the same lines, in vitro preclinical studies that explore potential toxicities of novel therapeutics on human PBMCs (e.g. cytokine release in the presence or absence of the drug and of recall Ag stimuli) would be beneficial [33].

\subsection{Immune biomarkers of immunological efficacy}

This is the trial monitoring application for which T-cell biomarkers can yield more information, especially in the context of tolerogenic Ag vaccination [50]. In terms of adverse reactivities, these can be defined by changes in (auto)immune responses in undesired directions, e.g. increased autoimmunity (autoAbs, islet specific CD4+ or CD8+ T-cell responses) or immune modulation skewed towards inflammation (IFN- $\gamma$, IL-17). Technologies are in place to define such adverse autoimmune responses, provided that these occur in the circulation or in skin reactions and at reasonably high intensity or frequency. Particularly in the case of Ag-specific immunotherapies, immune responses to the islet Ag of choice may be specifically measured in terms of quality and quantity, but the relatively low precursor frequencies of islet-reactive $T$ 
cells, in particular in the case of CD4+ T cells, may hamper their reliable, sensitive and robust identification.

One study was recently reported on autoAb+ diabetic patients not requiring insulin at the time of diagnosis. These patients were intranasally vaccinated with insulin or placebo in an attempt to save residual $\beta$ cells [51]. Although nasal insulin-treated patients eventually progressed towards insulin dependency at a rate similar to the placebo arm, successful induction of insulin-specific immune tolerance was documented both at the T-cell and Ab level [51]. Contrary to the placebo arm, patients treated with intranasal insulin displayed marked reductions in IFN- $\gamma-$ secreting T-cell responses to PI. This effect was Ag-specific, since it was not observed for the tetanus toxoid recall Ag. Once insulin therapy intiated, intranasal insulin-treated subjects also failed to develop anti-insulin Abs, further documenting that this PI-specific tolerance was operational in vivo [51].

Another example of immunological efficacy assessed through immune biomarkers comes from the Diamyd GAD-alum subcutaneous vaccination trial performed on new-onset T1D adolescents in Sweden [38]. Results of T-cell monitoring were different in this case, showing that GAD-alum, but not placebo treatment, did not blunt, but instead selectively boosted GAD-specific T-cell responses. Moreover, these T-cell responses did not shown a tolerogenic deviation towards secretion of Th2 or regulatory cytokines, as Th1 cytokines were equally produced. Furthermore, patients displaying a better clinical outcome (i.e. C-peptide decline $\leq 60 \%$ ) were also characterized by GAD-induced T-cell responses more deviated towards favorable Th2 (IL-5, IL-13) and regulatory (IL-10) cytokine profiles. These results suggest that, in the case of GAD-alum vaccination, the immune modifications induced are not selectively driven towards the desired outcome. 
Other recent examples of specific changes in immune responses to islet epitopes in Ag-specific immune responses in a favorable direction include immune modulation with the heat-shock protein-derived peptide DiaPep277 or PI, even though these do not necessarily associate with clinical benefit $[52,53]$. Yet, such immunological changes may point to mechanisms of action and as such point to another relevant incentive for immune monitoring efforts in the context of intervention studies.

\subsection{Immune biomarkers of therapeutic clinical efficacy}

The previous examples gathered from intranasal insulin, GAD and peptide vaccination trials exemplify how T-cell surrogates of immunological efficacy do not need to be identical to those associated with clinical efficacy. In fact, it is relevant to learn whether a given immunotherapy achieved the desired immune modification, despite failure to affect T1D progression [7]. As explained before, we argue that immune surrogates of failed clinical efficacy are equally useful to guide data interpretation and to inform further trial design. However, several cases have recently emerged of immune biomarkers that either predict or associate with clinical benefit from immunotherapy. Intriguingly, immune correlates that predict clinical outcome may not necessarily be the same as those that follow successful immune intervention. For instance, an immune response manifested by IL-10 production to DiaPep277 before therapy correlated with preserved $\beta$-cell function (regardless of subsequent DiaPep277 injection), but after treatment, all treated patients elicited an IL-10 response to DiaPep277, regardless of whether $\beta$-cell function was preserved or not. Instead, loss of a proliferative T-cell response to DiaPep277 following therapy correlated with clinical benefit in terms of preserved $\beta$-cell function [52]. This example also illustrates how immune correlates may differ before and after therapy. 


\subsection{Immune correlates of remission and relapse in islet transplantation}

A perhaps easier opportunity than monitoring natural progression and therapeutic intervention shortly after disease onset is provided by clinical islet transplantation [ 54 , 55]. Even though this setting is more complicated in the sense that alloreactivity to the islet allograft donor and concomitant immunosuppression adds to the complexity determining the in vivo fate of transplanted islets, the timelines are more concrete and synchronized with the defined time of re-introduction of islet Ags. Indeed, several important lessons have already been drawn from immune monitoring efforts. These include the overwhelming importance of (auto)immune memory (causing recurrence of autoimmune $\beta$-cell destruction and loss of graft function) [56]; the definition of baseline immune correlates affecting and predicting clinical efficacy (such as simple $\mathrm{T}$ and B-lymphocyte counts, baseline $\mathrm{CD} 4^{+}$or $\mathrm{CD} 8^{+} \mathrm{T}$-cell autoreactivity) $[16,57,58]$ that may allow staging of patients with superior or inferior clinical benefits; and the importance of matching of islet recipients with donors, and between donors in the case of repeated grafting $[59,60]$.

The significance of islet autoAbs at the time of islet transplantation as adverse immune parameter is more controversial and depending on the particular type of induction therapy (daclizumab, basilixumab, thymoglobulin or alemtuzumab) and maintenance immune suppressive therapy after transplantation (steroids, tacrolimus, sirolimus and/or mycophenolate mofetil). Beyond doubt, pre-existing donor-specific allo-Abs are detrimental, while thyroid autoAbs (anti-thyroid peroxidase) at baseline are highly predictive of development of Graves' disease after tapering of immune suppression following loss of islet allograft function [61-63]. Changes in titres or recurrence and spreading of islet autoAb reactivities are associated with chronic loss 
of $\beta$-cell function in most studies, but are not necessarily predictive of the future fate of the islet allograft [29, 64, 65].

Robust immune signatures of success as well as failures have been defined following islet engraftment that may differ among immune suppressive regimes [66, 67]. Important lessons are emerging from immune monitoring that may help guiding the choice of immune suppressive therapies. For instance, HLA Class I mismatching may avoid acute recurrence of $\mathrm{CD}^{+}{ }^{-}$-cell autoreactivity, whereas sirolimus-containing immune suppressive regimens add allo-reactivity as a factor contributing to loss of $\beta$ cell function. Furthermore, immune monitoring studies increased our understanding of the mode of action of therapeutics and identified potential causes of T1D recurrence or drug failure (e.g., homeostatic expansion of islet-reactive memory T cells following debulking induction therapies) [68]. Preliminary studies on the effect of tapering of immune suppression after islet transplantation suggest that immune correlates can be defined that help guiding the tapering process [69]. In terms of favorable immunological outcome, the development of a donor-specific IL-10 response in a mixed lymphocyte reaction associated with remission, whereas a proliferative response to donor HLA associated with relapse and loss of islet allograft function [58].

Collectively, the various immune studies underscore the importance of addressing immune memory, as most immunosuppressive drugs employed for islet transplantation are chosen for their capacity to prevent rejection rather than to intervene in immunologically primed conditions such as chronic autoimmunity. New intervention strategies that specifically address autoimmune memory are required to improve transplantation outcomes and it is conceivable that immune biomarkers may assist in identifying and validating such strategies. 


\section{Some unmet needs for T1D immune staging in immune therapeutic trials}

The large majority of T-cell-based immune staging studies have been performed to monitor modifications induced following immune therapy. One aspect that needs more emphasis is that of immune staging before intervention, to identify T-cell profiles associated with clinical responses and thus to help selecting which patients to treat. Specific autoAb specificities (e.g. anti-GAD in the Diamyd GAD trial) have already been used as selection criteria in several immune intervention trials. The rationale is to treat with a given $\mathrm{Ag}$ only those patients who show auto $\mathrm{Ab}$ evidence that the administered $\mathrm{Ag}$ is a target of active autoimmunity, and thus that there are responses amenable to therapeutic deviation through $\mathrm{Ag}$ administration. Indeed, there is little rationale to intervene on GAD-specific immune responses without evidence that these responses are active in a given patient. It should be noted however that formal proof for this rationale is lacking, as this would require treating for example with GAD-alum both anti-GAD autoAb-positive and -negative patients to resolve whether autoAb-positive vaccinees achieve better outcomes. However, results from the oral arm of the DPT- 1 trial suggest that this autoAb-based selection strategy may be of relevance. In this trial, at-risk relatives of $\mathrm{T} 1 \mathrm{D}$ patients were treated with oral insulin or placebo. Although the overall protection was not significant, post-hoc analyses of patients with starting higher IAA titers showed some protection [70]. Trial enrollment based on pre-treatment T-cell profiles may also improve clinical outcome, as suggested by the results discussed above for the DiaPep277 trial [52].

Another gap in knowledge concerns the possibility to follow modifications of Agspecific Tregs. Several types of Tregs have been identified, including both CD4+ and 
CD8+ T cells producing large amounts of IL-10 and TGF- $\beta$. It appears that in nondiabetic individuals, potentially pathogenic T cells are held in check by various Tregdependent mechanisms. T1D may develop due, at least in part, to a defect (either functional or numerical) in the Treg repertoire or resilience of islet-reactive $\mathrm{T}$ cells to be suppressed [71]. Due to side effects associated with long-term generalized immunosuppression, the induction and maintenance of long-lasting tolerance specific to islet Ags remains a major focus for T1D clinical trials. Hence, to monitor the efficacy of these trials, assays are urgently required that are able to measure not only the decline in pro-inflammatory effector $\mathrm{T}$ cells, but also the expansion of isletspecific Tregs. The definition of the Ag specificity of Tregs is required to this end. Islet Ag-specific Tregs in non-diabetic individuals have been described that are capable of suppressing the proliferation of $\mathrm{T}$ cells recently activated by insulin [72]. These studies indicate that islet-specific Tregs exist and can be detected in peripheral blood. While this further supports the possibility that islet-specific tolerance may be restored therapeutically, it also poses additional challenges for detecting cellular islet autoimmunity, as Treg-mediated suppression may mask such autoimmunity and impair functional assays aimed at monitoring it.

Contrary to other autoimmune diseases, direct bioptic access to damaged islets is not available for T1D. Islet imaging is thus being intensively investigated. Magnetic resonance imaging (MRI) has thus far provided the most promising results, as it may offer two key elements: quantification of the islet mass and infiltration by immune cells. Gaglia et al. applied a MRI strategy to patients by intravenously injecting magnetic ferrous nanoparticles [73]. These nanoparticles accumulate in inflamed tissues owing to heightened vascular permeability and, upon extravasation, uptake by infiltrating phagocytes recruited at this site. Increased signal accumulation was 
thus observed in pancreata of T1D patients compared to healthy individuals $48 \mathrm{~h}$ after nanoparticle injection, although no comparison with non-autoimmune T2D patients was performed. This is a critical control as low-grade islet inflammation is also present in T2D [74]. While MRI has high spatial resolution but low sensitivity, positron emission tomography (PET) has poorer spatial resolution but higher sensitivity. Therefore, combined PET and MRI techniques, in combination with specific imaging probes, may offer comprehensive functional and anatomical imaging of islet $\beta$ cells and their infiltrates [75], which may also help in solving the current uncertainty about the correlation between residual $\beta$-cell mass and insulin secretion.

\section{Present and future: immune biomarkers for therapeutic tailoring}

Immune surrogate endpoints should be systematically added to clinical and metabolic outcomes in order to comprehensively evaluate trial results. At present, this would allow:

1) To understand therapeutic mechanisms behind clinical efficacy.

2) To sort out the reasons for lack of clinical efficacy in many trials: is the intervention immunologically ineffective or is the immune effect insufficient to translate into clinical benefit?

3) To define pre-treatment and post-treatment immune profiles associated with clinical benefits.

Following wider implementation of these immune surrogate endpoints, the information gathered could allow:

1) To further explore therapeutic strategies inducing the desired immune modifications, even in the absence of clinical benefit. Following appropriate modifications in formulation, regimens, association with other agents or targeted 
patient population, such strategies may increase chances of achieving clinical efficacy.

2) To perform trials of smaller size, using immune surrogate endpoints for which expected changes are wider than for metabolic and clinical endpoints.

3) To perform trials of shorter duration, using early immune surrogate endpoints rather than late metabolic and clinical endpoints.

4) To encourage trial implementation at an earlier stage of disease (i.e. for T1D prevention in at-risk subjects) once data about safety and immune efficacy is obtained in new-onset T1D patients, independent of clinical outcome;

5) To improve enrollement strategies, based on pre-treatment immune profiles associated with clinical benefit;

6) To tailor immune therapies for each subject, both in terms of therapeutic agent (based on pre-treatment staging) and of treatment dose and duration (based on immune monitoring during treatment);

The challenge for the coming decade is to refine and harness this knowledge to design effective and safe intervention strategies, to construct monitoring algorithms for use in intervention studies and islet transplantation, and to achieve greater insight into triggers, accelerants and modulators of T-cell autoimmunity.

\section{Acknowledgements}

Work reviewed in this article was supported by grants from JDRF (1-2008-106 and 17-2012-559), the European Foundation for the Study of Diabetes (EFSD/JDRF/Novo Nordisk Programme in Type 1 Diabetes Research 2009), ANR Blanc Immunotolerins and INSERM Avenir (to R.M.); and by grants from JDRF (172011-660 \& 17-2012-547), the Dutch Diabetes Research Foundation, The European 
Commission (EU-FP7; BetaCellTherapy, NAIMIT and EE-ASI) and the National Research Council (VICl Award, ZonMW) (to B.O.R.). 


\section{References}

[1] B.O. Roep, J. Buckner, S. Sawcer, R. Toes, F. Zipp, The problems and promises of research into human immunology and autoimmune disease, Nat. Med., 18 (2012) 48-53.

[2] T.P. Di Lorenzo, M. Peakman, B.O. Roep, Translational mini-review series on type 1 diabetes: Systematic analysis of T cell epitopes in autoimmune diabetes, Clin. Exp. Immunol., 148 (2007) 1-16.

[3] J.M. Wenzlau, K. Juhl, L. Yu, O. Moua, S.A. Sarkar, P. Gottlieb, M. Rewers, G.S. Eisenbarth, J. Jensen, H.W. Davidson, J.C. Hutton, The cation efflux transporter ZnT8 (Slc30A8) is a major autoantigen in human type 1 diabetes, Proc. Natl. Acad. Sci. U.S.A., 104 (2007) 17040-17045.

[4] M. Scotto, G. Afonso, E. Larger, C. Raverdy, F.A. Lemonnier, J.C. Carel, D. Dubois-Laforgue, B. Baz, D. Levy, J.F. Gautier, O. Launay, G. Bruno, C. Boitard, L.A. Sechi, J.C. Hutton, H.W. Davidson, R. Mallone, Zinc transporter (ZnT)8(186-194) is an immunodominant CD8 (+) T cell epitope in HLA-A2 (+) type 1 diabetic patients, Diabetologia, 55 (2012) 2026-2031.

[5] B.O. Roep, T-cell responses to autoantigens in IDDM. The search for the Holy Grail, Diabetes, 45 (1996) 1147-1156.

[6] P.J. Bingley, E. Bonifacio, A.G. Ziegler, D.A. Schatz, M.A. Atkinson, G.S. Eisenbarth, Proposed guidelines on screening for risk of type 1 diabetes, Diabetes Care, 24 (2001) 398.

[7] S. Culina, R. Mallone, Immune biomarkers in immunotherapeutic trials for type 1 diabetes: Cui prodest?, Diabetes Metab., 38 (2012) 379-385.

[8] K.T. Coppieters, F. Dotta, N. Amirian, P.D. Campbell, T.W. Kay, M.A. Atkinson, B.O. Roep, M.G. von Herrath, Demonstration of islet-autoreactive CD8 T cells in insulitic lesions from recent onset and long-term type 1 diabetes patients, J. Exp. Med., 209 (2012) 51-60.

[9] G.S. Eisenbarth, Banting Lecture 2009: An unfinished journey: molecular pathogenesis to prevention of type 1A diabetes, Diabetes, 59 (2010) 759-774.

[10] J.C. Voltarelli, C.E. Couri, A.B. Stracieri, M.C. Oliveira, D.A. Moraes, F. Pieroni, M. Coutinho, K.C. Malmegrim, M.C. Foss-Freitas, B.P. Simoes, M.C. Foss, E. Squiers, R.K. Burt, Autologous nonmyeloablative hematopoietic stem cell transplantation in newly diagnosed type 1 diabetes mellitus, JAMA, 297 (2007) 15681576.

[11] R. Mallone, V. Brezar, To B or Not to B: (Anti)bodies of Evidence on the Crime Scene of Type 1 Diabetes?, Diabetes, 60 (2011) 2020-2022. 
[12] N. Sherry, W. Hagopian, J. Ludvigsson, S.M. Jain, J. Wahlen, R.J. Ferry, Jr., B. Bode, S. Aronoff, C. Holland, D. Carlin, K.L. King, R.L. Wilder, S. Pillemer, E. Bonvini, S. Johnson, K.E. Stein, S. Koenig, K.C. Herold, A.G. Daifotis, Teplizumab for treatment of type 1 diabetes (Protege study): 1-year results from a randomised, placebo-controlled trial, Lancet, 378 (2011) 487-497.

[13] J.F. Bach, Anti-CD3 antibodies for type 1 diabetes: beyond expectations, Lancet, 378 (2011) 459-460.

[14] A. Toma, S. Haddouk, J.P. Briand, L. Camoin, H. Gahery, F. Connan, D. Dubois-Laforgue, S. CaillatZucman, J.G. Guillet, J.C. Carel, S. Muller, J. Choppin, C. Boitard, Recognition of a subregion of human proinsulin by class I-restricted T cells in type 1 diabetic patients, Proc. Natl. Acad. Sci. U.S.A., 102 (2005) 10581-10586.

[15] R. Mallone, E. Martinuzzi, P. Blancou, G. Novelli, G. Afonso, M. Dolz, G. Bruno, L. Chaillous, L. Chatenoud, J.M. Bach, P. van Endert, CD8+ T-cell responses identify beta-cell autoimmunity in human type 1 diabetes, Diabetes, 56 (2007) 613-621.

[16] J.H. Velthuis, W.W. Unger, J.R. Abreu, G. Duinkerken, K. Franken, M. Peakman, A.H. Bakker, S. RekerHadrup, B. Keymeulen, J.W. Drijfhout, T.N. Schumacher, B.O. Roep, Simultaneous Detection of Circulating Autoreactive CD8+ T-Cells Specific for Different Islet Cell-Associated Epitopes Using Combinatorial MHC Multimers, Diabetes, 59 (2010) 1721-1730.

[17] M. Scotto, G. Afonso, T. Osterbye, E. Larger, S. Luce, C. Raverdy, G. Novelli, G. Bruno, C. GonfroyLeymarie, O. Launay, F.A. Lemonnier, S. Buus, J.C. Carel, C. Boitard, R. Mallone, HLA-B7-Restricted Islet Epitopes Are Differentially Recognized in Type 1 Diabetic Children and Adults and Form Weak Peptide-HLA Complexes, Diabetes, 61 (2012) 2546-2555.

[18] G.G. Pinkse, O.H. Tysma, C.A. Bergen, M.G. Kester, F. Ossendorp, P.A. van Veelen, B. Keymeulen, D. Pipeleers, J.W. Drijfhout, B.O. Roep, Autoreactive CD8 T cells associated with beta cell destruction in type 1 diabetes, Proc. Natl. Acad. Sci. U.S.A., 102 (2005) 18425-18430.

[19] E. Enee, E. Martinuzzi, P. Blancou, J.M. Bach, R. Mallone, P. van Endert, Equivalent specificity of peripheral blood and islet-infiltrating CD8+ T lymphocytes in spontaneously diabetic HLA-A2 transgenic NOD mice, J. Immunol., 180 (2008) 5430-5438.

[20] S. Arif, T.I. Tree, T.P. Astill, J.M. Tremble, A.J. Bishop, C.M. Dayan, B.O. Roep, M. Peakman, Autoreactive $\mathrm{T}$ cell responses show proinflammatory polarization in diabetes but a regulatory phenotype in health, J. Clin. Invest., 113 (2004) 451-463. 
[21] S. Arif, F. Moore, K. Marks, T. Bouckenooghe, C.M. Dayan, R. Planas, M. Vives-Pi, J. Powrie, T. Tree, P. Marchetti, G.C. Huang, E.N. Gurzov, R. Pujol-Borrell, D.L. Eizirik, M. Peakman, Peripheral and islet interleukin-17 pathway activation characterizes human autoimmune diabetes and promotes cytokine-mediated beta-cell death, Diabetes, 60 (2011) 2112-2119.

[22] S. Luce, F. Lemonnier, J.P. Briand, J. Coste, N. Lahlou, S. Muller, E. Larger, B. Rocha, R. Mallone, C. Boitard, Single Insulin-Specific CD8+ T Cells Show Characteristic Gene Expression Profiles in Human Type 1 Diabetes, Diabetes, 60 (2011) 3289-3299.

[23] A. Skowera, R.J. Ellis, R. Varela-Calvino, S. Arif, G.C. Huang, C. Van-Krinks, A. Zaremba, C. Rackham, J.S. Allen, T.I. Tree, M. Zhao, C.M. Dayan, A.K. Sewell, W. Unger, J.W. Drijfhout, F. Ossendorp, B.O. Roep, M. Peakman, CTLs are targeted to kill beta cells in patients with type 1 diabetes through recognition of a glucose-regulated preproinsulin epitope, J. Clin. Invest., 118 (2008) 3390-3402.

[24] D. Kronenberg, R.R. Knight, M. Estorninho, R.J. Ellis, M.G. Kester, A. de Ru, M. Eichmann, G.C. Huang, J. Powrie, C.M. Dayan, A. Skowera, P.A. van Veelen, M. Peakman, Circulating Preproinsulin Signal PeptideSpecific CD8 T Cells Restricted by the Susceptibility Molecule HLA-A24 Are Expanded at Onset of Type 1 Diabetes and Kill beta-Cells, Diabetes, 61 (2012) 1752-1759.

[25] A.G. van Halteren, M.J. Kardol, A. Mulder, B.O. Roep, Homing of human autoreactive T cells into pancreatic tissue of NOD-scid mice, Diabetologia, 48 (2005) 75-82.

[26] I. Jarchum, J.C. Baker, T. Yamada, T. Takaki, M.P. Marron, D.V. Serreze, T.P. DiLorenzo, In vivo cytotoxicity of insulin-specific CD8+ T-cells in HLA-A*0201 transgenic NOD mice, Diabetes, 56 (2007) 25512560.

[27] W.W. Unger, T. Pearson, J.R. Abreu, S. Laban, A.R. van der Slik, S.M. der Kracht, M.G. Kester, D.V. Serreze, L.D. Shultz, M. Griffioen, J.W. Drijfhout, D.L. Greiner, B.O. Roep, Islet-Specific CTL Cloned from a Type 1 Diabetes Patient Cause Beta-Cell Destruction after Engraftment into HLA-A2 Transgenic NOD/SCID/IL2RG Null Mice, PLoS One, 7 (2012) e49213.

[28] E. Martinuzzi, G. Novelli, M. Scotto, P. Blancou, J.M. Bach, L. Chaillous, G. Bruno, L. Chatenoud, E.P. van, R. Mallone, The frequency and immunodominance of islet-specific CD8+ T-cell responses change after type 1 diabetes diagnosis and treatment, Diabetes, 57 (2008) 1312-1320.

[29] F. Vendrame, A. Pileggi, E. Laughlin, G. Allende, A. Martin-Pagola, R.D. Molano, S. Diamantopoulos, N. Standifer, K. Geubtner, B.A. Falk, H. Ichii, H. Takahashi, I. Snowhite, Z. Chen, A. Mendez, L. Chen, J. Sageshima, P. Ruiz, G. Ciancio, C. Ricordi, H. Reijonen, G.T. Nepom, G.W. Burke, III, A. Pugliese, Recurrence 
of type 1 diabetes after simultaneous pancreas-kidney transplantation, despite immunosuppression, is associated with autoantibodies and pathogenic autoreactive CD4 T-cells, Diabetes, 59 (2010) 947-957.

[30] P. Kulmala, K. Savola, J.S. Petersen, P. Vahasalo, J. Karjalainen, T. Lopponen, T. Dyrberg, H.K. Akerblom, M. Knip, Prediction of insulin-dependent diabetes mellitus in siblings of children with diabetes. A population-based study. The Childhood Diabetes in Finland Study Group, J. Clin. Invest., 101 (1998) 327-336.

[31] D.J. Klinke, 2nd, Extent of beta cell destruction is important but insufficient to predict the onset of type 1 diabetes mellitus, PLoS One, 3 (2008) e1374.

[32] C.J. Greenbaum, T. Mandrup-Poulsen, P.F. McGee, T. Battelino, B. Haastert, J. Ludvigsson, P. Pozzilli, J.M. Lachin, H. Kolb, Mixed-meal tolerance test versus glucagon stimulation test for the assessment of beta-cell function in therapeutic trials in type 1 diabetes, Diabetes Care, 31 (2008) 1966-1971.

[33] B.O. Roep, M. Peakman, Surrogate end points in the design of immunotherapy trials: emerging lessons from type 1 diabetes, Nat. Rev. Immunol., 10 (2010) 145-152.

[34] B. Keymeulen, E. Vandemeulebroucke, A.G. Ziegler, C. Mathieu, L. Kaufman, G. Hale, F. Gorus, M. Goldman, M. Walter, S. Candon, L. Schandene, L. Crenier, B.C. De, J.M. Seigneurin, P.P. De, D. Pierard, I. Weets, P. Rebello, P. Bird, E. Berrie, M. Frewin, H. Waldmann, J.F. Bach, D. Pipeleers, L. Chatenoud, Insulin needs after CD3-antibody therapy in new-onset type 1 diabetes, N. Engl. J. Med., 352 (2005) 2598-2608.

[35] M.D. Pescovitz, C.J. Greenbaum, H. Krause-Steinrauf, D.J. Becker, S.E. Gitelman, R. Goland, P.A. Gottlieb, J.B. Marks, P.F. McGee, A.M. Moran, P. Raskin, H. Rodriguez, D.A. Schatz, D. Wherrett, D.M. Wilson, J.M. Lachin, J.S. Skyler, Rituximab, B-lymphocyte depletion, and preservation of beta-cell function, N. Engl. J. Med., 361 (2009) 2143-2152.

[36] L. Yu, K. Herold, H. Krause-Steinrauf, P.L. McGee, B. Bundy, A. Pugliese, J. Krischer, G.S. Eisenbarth, Rituximab selectively suppresses specific islet antibodies, Diabetes, 60 (2011) 2560-2565.

[37] J. Ludvigsson, M. Faresjo, M. Hjorth, S. Axelsson, M. Cheramy, M. Pihl, O. Vaarala, G. Forsander, S. Ivarsson, C. Johansson, A. Lindh, N.O. Nilsson, J. Aman, E. Ortqvist, P. Zerhouni, R. Casas, GAD treatment and insulin secretion in recent-onset type 1 diabetes, N. Engl. J. Med., 359 (2008) 1909-1920.

[38] S. Axelsson, M. Cheramy, M. Hjorth, M. Pihl, L. Akerman, E. Martinuzzi, R. Mallone, J. Ludvigsson, R. Casas, Long-Lasting Immune Responses 4 Years after GAD-Alum Treatment in Children with Type 1 Diabetes, PLoS One, 6 (2011) e29008.

[39] H. Reijonen, T.L. Daniels, A. Lernmark, G.T. Nepom, GAD65-specific autoantibodies enhance the presentation of an immunodominant T-cell epitope from GAD65, Diabetes, 49 (2000) 1621-1626. 
[40] L.C. Harrison, M.C. Honeyman, C.E. Steele, N.L. Stone, E. Sarugeri, E. Bonifacio, J.J. Couper, P.G. Colman, Pancreatic beta-cell function and immune responses to insulin after administration of intranasal insulin to humans at risk for type 1 diabetes, Diabetes Care, 27 (2004) 2348-2355.

[41] V. Brezar, J.C. Carel, C. Boitard, R. Mallone, Beyond the hormone: insulin as an autoimmune target in type 1 diabetes, Endocr. Rev., 32 (2011) 623-669.

[42] V. Brezar, S. Culina, M.C. Gagnerault, R. Mallone, Short-term subcutaneous insulin treatment delays but does not prevent diabetes in NOD mice, Eur. J. Immunol., 42 (2012) 1553-1561.

[43] C.M. Britten, S. Janetzki, L.H. Butterfield, G. Ferrari, C. Gouttefangeas, C. Huber, M. Kalos, H.I. Levitsky, H.T. Maecker, C.J. Melief, J. O'Donnell-Tormey, K. Odunsi, L.J. Old, T.H. Ottenhoff, C. Ottensmeier, G. Pawelec, M. Roederer, B.O. Roep, P. Romero, S.H. van der Burg, S. Walter, A. Hoos, M.M. Davis, T cell assays and MIATA: the essential minimum for maximum impact, Immunity, 37 (2012) 1-2.

[44] R. Mallone, S.I. Mannering, B.M. Brooks-Worrell, I. Durinovic-Bello, C.M. Cilio, F.S. Wong, N.C. Schloot, Isolation and preservation of peripheral blood mononuclear cells for analysis of islet antigen-reactive T cell responses: position statement of the T-Cell Workshop Committee of the Immunology of Diabetes Society, Clin. Exp. Immunol., 163 (2011) 33-49.

[45] M. Peakman, T.I. Tree, J. Endl, E.P. van, M.A. Atkinson, B.O. Roep, Characterization of preparations of GAD65, proinsulin, and the islet tyrosine phosphatase IA-2 for use in detection of autoreactive T-cells in type 1 diabetes: report of phase II of the Second International Immunology of Diabetes Society Workshop for Standardization of T-cell assays in type 1 diabetes, Diabetes, 50 (2001) 1749-1754.

[46] B.O. Roep, M.A. Atkinson, P.M. van Endert, P.A. Gottlieb, S.B. Wilson, J.A. Sachs, Autoreactive T cell responses in insulin-dependent (Type 1) diabetes mellitus. Report of the first international workshop for standardization of T cell assays, J. Autoimmun., 13 (1999) 267-282.

[47] S.I. Mannering, F.S. Wong, I. Durinovic-Bello, B. Brooks-Worrell, T.I. Tree, C.M. Cilio, N.C. Schloot, R. Mallone, Current approaches to measuring human islet-antigen specific T cell function in type 1 diabetes, Clin. Exp. Immunol., 162 (2010) 197-209.

[48] B. Bielekova, B. Goodwin, N. Richert, I. Cortese, T. Kondo, G. Afshar, B. Gran, J. Eaton, J. Antel, J.A. Frank, H.F. McFarland, R. Martin, Encephalitogenic potential of the myelin basic protein peptide (amino acids 83-99) in multiple sclerosis: results of a phase II clinical trial with an altered peptide ligand, Nat. Med., 6 (2000) 1167-1175.

[49] M.M. Davis, A prescription for human immunology, Immunity, 29 (2008) 835-838. 
[50] S. Culina, C. Boitard, R. Mallone, Antigen-based immune therapeutics for type 1 diabetes: magic bullets or ordinary blanks?, Clin. Dev. Immunol., 2011 (2011) 286248.

[51] S. Fourlanos, C. Perry, S.A. Gellert, E. Martinuzzi, R. Mallone, J. Butler, P.G. Colman, L.C. Harrison, Evidence that nasal insulin induces immune tolerance to insulin in adults with autoimmune diabetes, Diabetes, 60 (2011) 1237-1245.

[52] V.A. Huurman, P.E. van der Meide, G. Duinkerken, S. Willemen, I.R. Cohen, D. Elias, B.O. Roep, Immunological efficacy of heat shock protein 60 peptide DiaPep277 therapy in clinical type I diabetes, Clin. Exp. Immunol., 152 (2008) 488-497.

[53] S.L. Thrower, L. James, W. Hall, K.M. Green, S. Arif, J.S. Allen, C. Van-Krinks, B. Lozanoska-Ochser, L. Marquesini, S. Brown, F.S. Wong, C.M. Dayan, M. Peakman, Proinsulin peptide immunotherapy in type 1 diabetes: report of a first-in-man Phase I safety study, Clin. Exp. Immunol., 155 (2009) 156-165.

[54] D.M. Harlan, N.S. Kenyon, O. Korsgren, B.O. Roep, Current advances and travails in islet transplantation, Diabetes, 58 (2009) 2175-2184.

[55] B.O. Roep, I. Stobbe, G. Duinkerken, J.J. van Rood, A. Lernmark, B. Keymeulen, D. Pipeleers, F.H. Claas, R.R. de Vries, Auto- and alloimmune reactivity to human islet allografts transplanted into type 1 diabetic patients, Diabetes, 48 (1999) 484-490.

[56] V.A. Huurman, R. Hilbrands, G.G. Pinkse, P. Gillard, G. Duinkerken, P. van de Linde, P.M. van der MeerPrins, M.F. Versteeg-van der Voort Maarschalk, K. Verbeeck, B.Z. Alizadeh, C. Mathieu, F.K. Gorus, D.L. Roelen, F.H. Claas, B. Keymeulen, D.G. Pipeleers, B.O. Roep, Cellular islet autoimmunity associates with clinical outcome of islet cell transplantation, PLoS One, 3 (2008) e2435.

[57] R. Hilbrands, V.A. Huurman, P. Gillard, J.H. Velthuis, M. De Waele, C. Mathieu, L. Kaufman, M. Pipeleers-Marichal, Z. Ling, B. Movahedi, D. Jacobs-Tulleneers-Thevissen, D. Monbaliu, D. Ysebaert, F.K. Gorus, B.O. Roep, D.G. Pipeleers, B. Keymeulen, Differences in baseline lymphocyte counts and autoreactivity are associated with differences in outcome of islet cell transplantation in type 1 diabetic patients, Diabetes, 58 (2009) 2267-2276.

[58] V.A. Huurman, J.H. Velthuis, R. Hilbrands, T.I. Tree, P. Gillard, P.M. van der Meer-Prins, G. Duinkerken, G.G. Pinkse, B. Keymeulen, D.L. Roelen, F.H. Claas, D.G. Pipeleers, B.O. Roep, Allograft-specific cytokine profiles associate with clinical outcome after islet cell transplantation, Am. J. Transplant., 9 (2009) 382-388. 
[59] I. Stobbe, G. Duinkerken, J.J. van Rood, A. Lernmark, B. Keymeulen, D. Pipeleers, R.R. De Vries, F.H. Glass, B.O. Roep, Tolerance to kidney allograft transplanted into Type I diabetic patients persists after in vivo challenge with pancreatic islet allografts that express repeated mismatches, Diabetologia, 42 (1999) 1379-1380. [60] C.A. van Kampen, P. van de Linde, G. Duinkerken, J.J. van Schip, D.L. Roelen, B. Keymeulen, D.G. Pipeleers, F.H. Claas, B.O. Roep, Alloreactivity against repeated HLA mismatches of sequential islet grafts transplanted in non-uremic type 1 diabetes patients, Transplantation, 80 (2005) 118-126.

[61] P.M. Campbell, A. Salam, E.A. Ryan, P. Senior, B.W. Paty, D. Bigam, T. McCready, A. Halpin, S. Imes, F. Al Saif, J.R. Lakey, A.M. Shapiro, Pretransplant HLA antibodies are associated with reduced graft survival after clinical islet transplantation, Am. J. Transplant., 7 (2007) 1242-1248.

[62] P.M. Campbell, P.A. Senior, A. Salam, K. Labranche, D.L. Bigam, N.M. Kneteman, S. Imes, A. Halpin, E.A. Ryan, A.M. Shapiro, High risk of sensitization after failed islet transplantation, Am. J. Transplant., 7 (2007) 2311-2317.

[63] P. Gillard, V. Huurman, B. Van der Auwera, B. Decallonne, K. Poppe, B.O. Roep, F. Gorus, C. Mathieu, D. Pipeleers, B. Keymeulen, Graves hyperthyroidism after stopping immunosuppressive therapy in type 1 diabetic Islet cell recipients with pretransplant TPO autoantibodies, Diabetes Care, 32 (2009) 1817-1819.

[64] E. Bosi, S. Braghi, P. Maffi, M. Scirpoli, F. Bertuzzi, G. Pozza, A. Secchi, E. Bonifacio, Autoantibody response to islet transplantation in type 1 diabetes, Diabetes, 50 (2001) 2464-2471.

[65] C. Jaeger, M.D. Brendel, M. Eckhard, R.G. Bretzel, Islet autoantibodies as potential markers for disease recurrence in clinical islet transplantation, Exp Clin Endocrinol Diabetes, 108 (2000) 328-333.

[66] P. Gillard, Z. Ling, C. Mathieu, L. Crenier, M. Lannoo, B. Maes, B. Roep, F. Gorus, D. Pipeleers, B. Keymeulen, Comparison of sirolimus alone with sirolimus plus tacrolimus in type 1 diabetic recipients of cultured islet cell grafts, Transplantation, 85 (2008) 256-263.

[67] D.L. Roelen, V.A. Huurman, R. Hilbrands, P. Gillard, G. Duinkerken, P.W. van der Meer-Prins, M.F. Versteeg-van der Voort Maarschalk, C. Mathieu, B. Keymeulen, D.G. Pipeleers, B.O. Roep, F.H. Claas, Relevance of cytotoxic alloreactivity under different immunosuppressive regimens in clinical islet cell transplantation, Clin. Exp. Immunol., 156 (2009) 141-148.

[68] P. Monti, M. Scirpoli, P. Maffi, N. Ghidoli, T.F. De, F. Bertuzzi, L. Piemonti, M. Falcone, A. Secchi, E. Bonifacio, Islet transplantation in patients with autoimmune diabetes induces homeostatic cytokines that expand autoreactive memory T cells, J. Clin. Invest., 118 (2008) 1806-1814. 
[69] V.A. Huurman, C.R. van der Torren, P. Gillard, R. Hilbrands, E.P. van der Meer-Prins, G. Duinkerken, F.K. Gorus, F.H. Claas, B. Keymeulen, D.L. Roelen, D.G. Pipeleers, B.O. Roep, Immune responses against islet allografts during tapering of immunosuppression--a pilot study in 5 subjects, Clin. Exp. Immunol., 169 (2012) 190-198.

[70] J.S. Skyler, J.P. Krischer, J. Wolfsdorf, C. Cowie, J.P. Palmer, C. Greenbaum, D. Cuthbertson, L.E. RafkinMervis, H.P. Chase, E. Leschek, Effects of oral insulin in relatives of patients with type 1 diabetes: The Diabetes Prevention Trial--Type 1, Diabetes Care, 28 (2005) 1068-1076.

[71] S. Culina, R. Mallone, Pathogenic and regulatory T cells in type 1 diabetes: losing self-control, restoring it, and how to take the temperature, Curr. Diab. Rep., 11 (2011) 426-433.

[72] T.I. Tree, J. Lawson, H. Edwards, A. Skowera, S. Arif, B.O. Roep, M. Peakman, Naturally arising human CD4 T cells that recognize islet autoantigens and secrete IL-10 regulate pro-inflammatory T cell responses via linked suppression, Diabetes, 59 (2010) 1451-1460.

[73] J.L. Gaglia, A.R. Guimaraes, M. Harisinghani, S.E. Turvey, R. Jackson, C. Benoist, D. Mathis, R. Weissleder, Noninvasive imaging of pancreatic islet inflammation in type 1A diabetes patients, J. Clin. Invest., 121 (2011) 442-445.

[74] J.A. Ehses, A. Perren, E. Eppler, P. Ribaux, J.A. Pospisilik, R. Maor-Cahn, X. Gueripel, H. Ellingsgaard, M.K. Schneider, G. Biollaz, A. Fontana, M. Reinecke, F. Homo-Delarche, M.Y. Donath, Increased number of islet-associated macrophages in type 2 diabetes, Diabetes, 56 (2007) 2356-2370.

[75] Z. Medarova, A. Moore, MRI as a tool to monitor islet transplantation, Nat. Rev. Endocrinol., 5 (2009) 444452. 


\section{Figure legends}

Figure 1. Biomarkers of prediction, prevention, diagnosis and intervention in type 1 diabetes. 


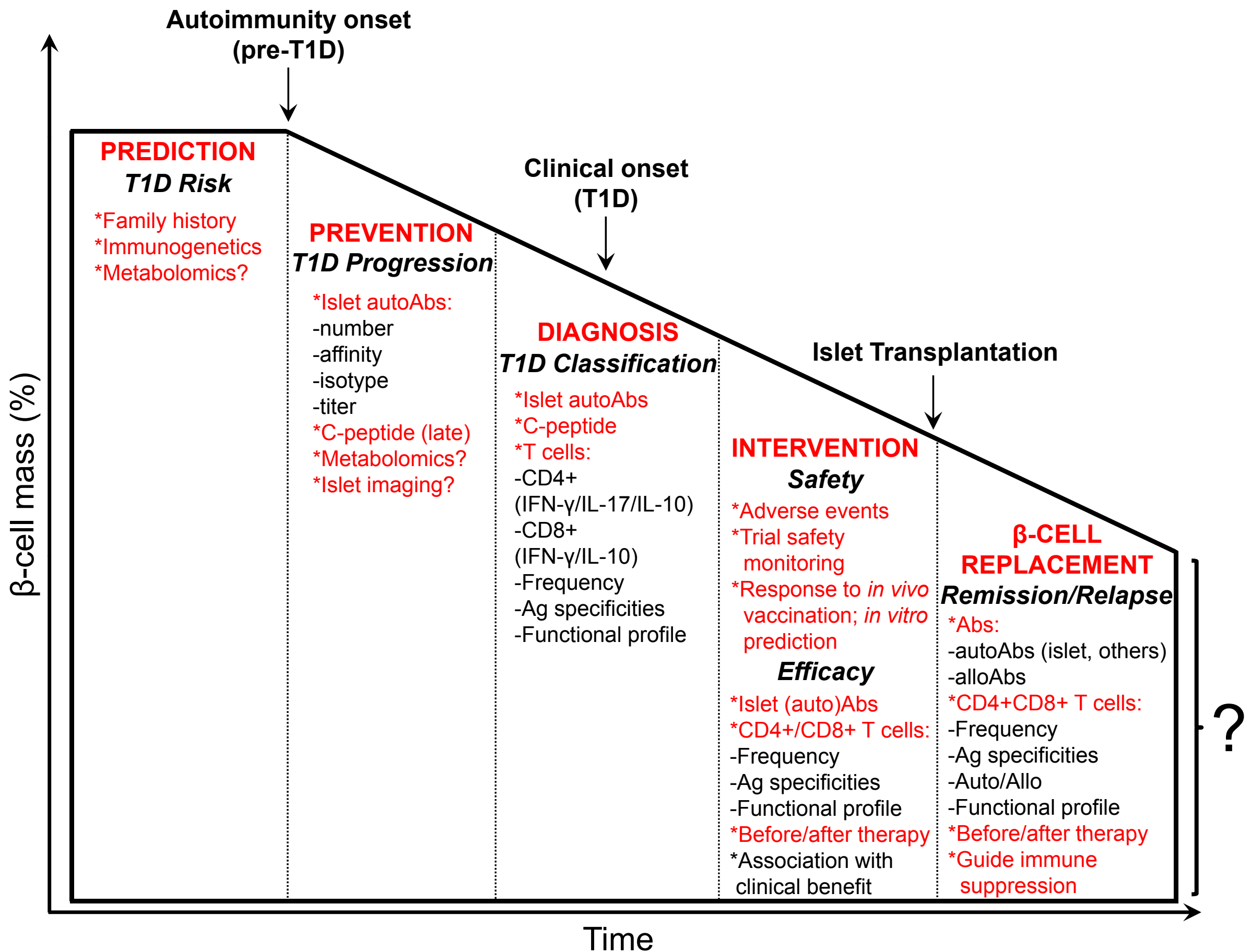

